\title{
THE SCIENTER REQUIREMENT AND RETROSPECTIVE CLAUSES IN LOYALTY OATHS
}

\author{
By JoHN E. Swanstron*
}

\section{Scienter}

Recent cases make evident the fact that loyalty oaths as a requirement for state employment are going to be a part of our everyday existence for some time to come. ${ }^{1}$ The problem for review in this article concerns not the ultimate desirability of such oaths as they may affect the welfare of the nation, but rather the narrower question of how we are to administer them effectively and reconcile their consequences with the letter and spirit of the Federal Constitution.

The current difficulties in loyalty oaths lie in two general areas. First, there is the danger that loyalty programs employing oaths will subject innocent persons to some form of persecution through guilt by association; and, secondly, denial of government employment to persons guilty of innocent, past membership in proscribed organizations, if permitted, may make such disclaimers little more than bills of attainder and ex post facto laws.

The Supreme Court of the United States has been consistent in requiring that oaths be administered in such a way that no person will be disqualified from employment because of membership in a

* 2d year law student, Duke University; A.B. Clark University, 1951.

${ }^{1}$ Garner v. Board of Public Works, 341 U. S. 716 (1951); Gerende v. Board of Supervisors, 341 U. S. 56 (1951); Adler v. Board of Educatiou, 342 U. S. 485 (1952) ; Wieman v. Updegraff, 344 U. S. 183 (1952); Washington v. Clark, 84 F. Supp. 964 (D. C. D. C. 1949); Steiner v. Dailey, 88 Cal. App. $2 d$ 481, 199 P. 2d 429, cert. denied 338 U. S. 327 (1948); Imbrie v. Marsh, 3 N. J. 578, 71 A. $2 d$ 352, 18 A. I. R. $2 d 241$ (1950); Thorpe v. Board of Trustees, 6 N. J. 498, 79 A. $2 d 462$ (1951); Dworken v. Collopy, - Ohio (Ct. C. P.) -, 91 N. E. $2 d 564$ (1950). See also state statutes excluding persons from stato employment through use of loyalty oaths or affidavits: ALAsKs. LAws, 1949, c. 113 , p. 290 , amending $\$ 11-1-8$ of ALASKa ConrP. LAws (1949); OAL. Govt. Code. 1023 and 19573 ; Fua. Laws 1949 , c. 25046, p. 102 ; GA. CODE ANN.

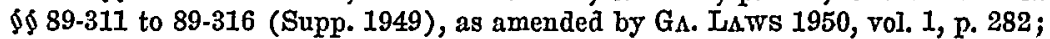
HaWAII REv. Laws $\$ \delta$ 600-616 (1945), as amended by HawaII Laws (1945), act 131 , p. 22 , as amended by HAWArr Laws (1947), act 117, p. 26; KAN. LAWs (1949), c. 246, 1 , p. 407; MD. ANN. CodE GEN. Laws Art. 85A, $\$ 10.18$; Mass. Ann. Laws c. 264, 13-15 (Supp. 1949); N. J. StaT. ANN. \$ $11: 1-1$ to $41: 1-3$ (Supp. 1949); ORE LaWs (1949), c. 311, c. 434, $\$ 14$; WasH. LaWs (1949), c. $242, \& 2$, p. 948 (note: Included in the 1949 state appropriations law). See, also, GellmorN, The States aNd Stbversion (1952). 
proscribed organization or affiliation with a prohibited activity alone without knowledge of the actual improper activities or purposes of the organization in question. ${ }^{2}$ This requirement of scienter raises perplexing problems. Does the listing by the Attorney General of the United States of "subversive" organizations constitute notice to members of improper purposes ?3 Does an oath, or a statute prescribing an oath, employ guilt by association if it speeifies an organization (usually the Communist Party) and requires that an employee specifically disclaim membership therein in addition to the general disclaimer of membership in any organization advocating the overthrow of the government by force and violence or other unconstitutional means ?

Several cases have settled the issue that no one may be discharged from his employment by the fact of membership alone in a "subversive" organization." New York's Feinberg Law, which provides that the Board of Regents shall compile a list of subversive organizations and that membership in any of them shall constitute prima facie evidence of disloyalty, places the burden upon the school teacher to show no knowledge of improper purposes and to rebut the presumption. This law has been upheld ${ }^{7}$ on the ground that scienter must appear before there can be any disqualification. This is the only statute in the United States which speeifically goes

s See summary in Wieman v. Updegraff, 344 U. S. 183 (1952).

"The list of "subversive" organizations compiled by the Attorney General pursuant to Exec. Order 9835, 12 FED. REG. 1938, 3 CFR, 1947 Supp., p. 129, though intended for use in the Loyalty Review Program for Federal Employees, where membership in such a proseribed organization is but "one piece of evidence" in a loyalty investigation (see 13 FED. REG. 6135, 5 CFR 200, 210, 1952 Supp.), has also found its way, as a ready made utensil, into state loyalty programs as is evidenced by the oath held invalid in Wieman v. Jpdegraff, supra note 2. Under that oath a person was to swear (or affirm) he was not affiliated with the Communist party "or of any agency, party, organization, association, or group whatever which has been officially determined by the United States Attorney General or other authorized public agency of the United States to be a communist front or subversive organization...." (Italics supplied.)

- See affidavit requirement of section 9 (h) of the NATIONAL LABOR RBLAmoNs ACT of 1947, 61 STAT. 136 (1947), 29 U. S. C. A. $\$ 159$ (h). Upheld in American Communications Assoc. v. Douds, 339 U. S. 382 (1950). See, also, the Oklahoma Oath in Wieman $\nabla$. Updegraff, infra note 13.

- Garner v. Board of Public Works, supra note 1; Gerende v. Board of Supervisors, supra note 1; Adler v. Board of Education, supra note 1; Wieman v. Updegraff, supra note 1 .

ON. Y. Educ. IaW $\oint 3022$ (1949), supplementing N. Y. Crv. Serv. Law $\$ 12-A$ and N. Y. Bduc. LAT $\$ 3021$.

- Adler v. Board of Education, supra note 1 . 
so far as to make membership alone a prima facie case of disloyalty. Since the Adler case, New York must carefully prevent the presumption from becoming conclusive.

Gerende v. Board of Supervisors ${ }^{8}$ held the Maryland Oath Act ${ }^{0}$ valid by reason of assurances that the Act would be administered so as to require scienter for disqualification by Maryland's attorney general.

Garner v. Board of Public Works ${ }^{10}$ upheld a similar oath required by the City of Los Angeles merely because the Supreme Court felt "justified in assuming that scienter was implicit in each clause of the oath."

However, the most recent case, Wieman $v$. Updegraff, ${ }^{11}$ held violative of the Due Process clause of the XIV Amendment an Oklahoma statute requiring an oath by all government employees which the Supreme Court of Oklahoma had interpreted to apply only to organizations listed by the Attorney General of the United States as "subversive" before the date of enactment. The oath contained no specific requirement of scienter and required a five year disclaimer of past membership. ${ }^{12}$ The oath was offensive in that it incorporated by reference the Attorney General's list and therefore substituted the judgment of the Attorney General for the opinion or knowledge of individual persons as to the characters and purposes of such organizations. This interpretation by the Oklahoma court making membership in a listed organization without actual proof of any knowledge of improper purposes sufficiently negatived any scienter requirement. No mention was made in the majority opinion by Mr. Justice Clark as to the validity or invalidity of the retrospective clause (see II below). The Olzlahoma oath also proscribed membership in the Communist Party specifically; but the court did not refer to that fact. It seems to follow however, that a "listing" of one organization by the legislature ought not to bear more weight than the listing by the Attorney General as a substitute for the individual's knowledge of the character and purposes of the organization in question.

If the court, as it seems to have done, rigorously requires that

${ }^{8}$ Supra, note 1. $\quad{ }^{\circ}$ Supra, note 1. ${ }^{20}$ Supra, note 1. ${ }^{11}$ Supra, noto 2.

12 The Los Angeles ordinance upheld in the Garner ease required a noucommunist disclaimer in the form of an affidavit in addition to the genoral loyalty oath. The court decided that the affidavit fell withiu the scope of relevant inquiry but did not determine the question of whether any disqualification could be imposed by reason of such admission. 341 U. S. at 720 . 
no person may be subject to disqualification from public employment or other office because of membership in any organization without further proof of actual knowledge of the improper purposes of such organization, it follows that a member of the Communist Party or any other listed organization cannot be disqualified without proof that the member knew that the party or organization advocates the overthrow of the government by force and violence, even if that organization must be specifically disclaimed in the oath. It remains to be decided, because of the failure to meet the issue in the $O p$ degraff decision, whether the specific disclaimer is constitutional in view of the fact that a member of the Communist Party or other organization cannot in good conscience take the oath even though there has been no determination of scienter..$^{13}$ It is unfortu-

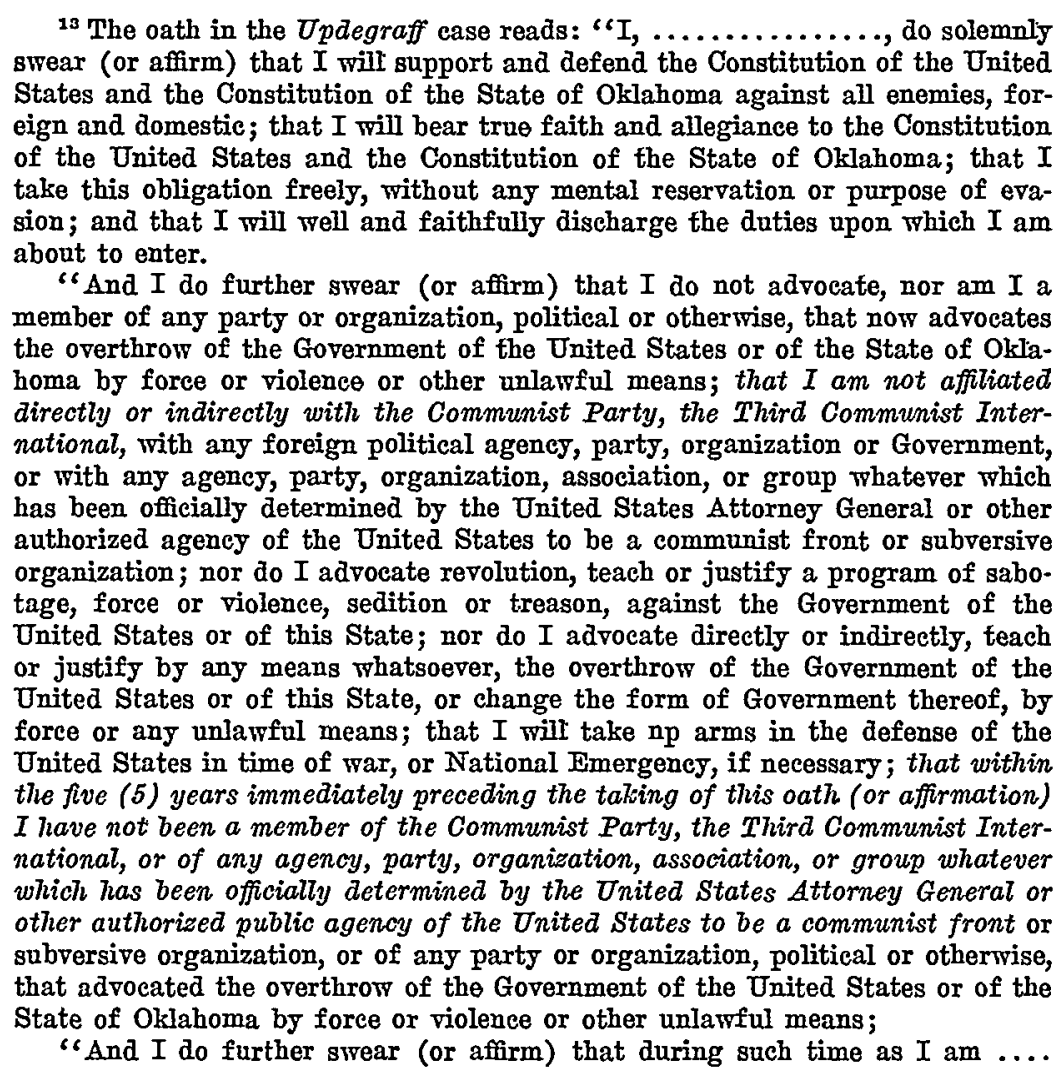

(Here put name of office, or, if employee,) insert 'An Employe of' followed 
nate that the Supreme Court did not see fit to decide this particular problem in the $\nabla_{p d e g r a f f}$ case when it had such an oath before it.

The trend unmistakably indicates, however, that no legislative or administrative determination as to the character and purposes of any organization can stand alone in the individual case without further actual evidence that the subscriber to any oath had actual knowledge of that purpose; and, that every individual is entitled to his own opinion as to the character of an organization. ${ }^{14}$ Only by rigid adherence to this principle can guilt by association be kept out of the loyalty sphere. ${ }^{15}$

\section{Retrospective Clauses}

Retrospective clauses frequently appearing in loyalty oaths require a disclaimer of membership in an organization with improper purposes within the five years preceding the taking of the oath. ${ }^{10}$ The Supreme Court has held that under certain circumstances such a clause is not an ex post facto law nor a bill of attainder. ${ }^{17}$ In the

by the complete designation of the employing officer, office, agency, authority, n............................

commission, department or institution.

"I will not advocate and that I will not become a member of any party or organization, political or otherwise, that advocates the overthrow of the Government of the United States or of the State of Oklahoma by force or violence or other unlawful means." (Italics snpplied.) 344 U. S. at 183.

${ }^{14}$ An older case, People v. MeClennegen, 195 Cal. 445, 234 Pac. 91 (1925), points up the danger. Proof of joining an organization shown to bo such as the statute denounced constituted a sufficient showing of knowledgo of the purposes of the organization. It would seem obvious that the faet proved, the act of joining, bears no necessary relation to the fact presumed, knowlodge of the improper purpose.

${ }^{15}$ See, Guilt by Association: Three Words in Search of a Mleaning, $17 \mathrm{U}$. OF CHI. L. REv. 148 (1949).

10 ". . . that within the five (5) years immediately preceding the taking of this oath (or affirmation) I have not been a member of the Communist party ...." OKra. StaT. ANN. 1950, Tit. 51 \$ 37.1-37.8 (1952 Supp.). ". . No person shall hold or retain or be eligible for any public office or employment in the service of the City of Los Angeles ... either elective or appointivo, who has within five (5) years prior to the effective date of this section advisod, advocated, or taught ... or who has within five (5) years prior to the effectivo date of this section, become a member of or affiliated with ... or has, within five (5) years, advised, advocated, or taught the overthrow by force. ..." oto. The 1941 Amend. to the Charter of TTEE CitTy of Los ANgeues. Ord. No. 94,004 (1948), implemented the above provision by drawing it into the form of an oath.

${ }^{17}$ Garner v. Board of Public Works, supra, note 1. 
Garner case, a charter amendment ${ }^{18}$ passed in 1941 set forth membership in organizations advocating overthrow of the government by force as a disqualification for employment by the City of Los Angeles. In 1947, an ordinance was passed by the city implementing the charter with an oath containing such a retrospective clause. ${ }^{19}$ It was upheld because whether denial of public employment is punishment or not, ${ }^{20}$ the retrospective clause only referred back to 1943 and thus did not retrospectively proseribe any conduct or affiliation which had not been already prohibited by the charter amendment of 1941. Justices Burton, Black, and Douglas, however, dissented on the ground that the retrospective clause did not impose a disqualification for innocent past affiliation. Justice Burton interpreted the oath and ordinance together to mean that the disclaimer referred back to activities during the five years prior to the effective date of the ordinance. ${ }^{21}$ In the $U_{\text {pdegraff case, the oath contained }}$ a similar retrospective disclaimer without the cloak of past, prohibited affiliation by charter relied upon by the majority in the Garner case. However, having invalidated the Oklahoma oath on scienter grounds, the court never reached the issue of retroactivity. Reasoning from the discussion in the Garner case, however, it seems evident that the Oklahoma oath did impose a disqualification for innocent, past affiliation and could not have been uphèld on the basis of the decision in the Garner case. Again, it is unfortunate that the court in Updegraff did not see fit to broaden its discussion and decide on the issue of retroactivity.

It has not been squarely determined whether or not denial or loss of public employment constitutes such punishment by a legisla-

${ }^{18}$ Supra, note 16.

19 Ibia.

no The leading cases holding statutes requiring oaths as to past conduct invalid are (1) Cummings v. Missouri, 4 Wall. 277 (U. S. 1867) and (2) Ex Parte Garland, 4 Wall. 333 (U. S. 1867). The court in Hawker v. New York, 170 U. S. 189 (1898), holding valid a statute prohibiting any person from practicing medicine who had previously committed a felony, distinguished the Cummings and Garland eases on the ground that the past conduct in those cases bore no relation to the activities the petitioners wished to pursue. The majority in the Garner case deseribed the oath there in question as a "general regulation which merely provides standards of qualification and eligibility for employment." 341 U. S. at 722. In a concurring opinion, Frankfurter, J., concedes that, "It would give to the Due Process Clause an unwarranted power of intrusion into local affairs to hold that a city may not require its employees to disclose whether they have been members of the Communist Party. . . ." 341 U. S. at 725. The court seems to say without deciding, that dismissal for failure to meet a valid qualification cannot be punishment. See note 22, infra. ${ }^{21} 341$ U. S. at 729 . 
tive act without judicial determination as to constitute such oaths acting retrospectively as bills of attainder. ${ }^{22}$ Justices Black, Burton, and Douglas consider such a denial or loss to be penal and also regard the retrospective clauses as ex post facto laws or bills of attainder in that they impose a penalty for acts which were not punishable at the time they were committed. The present majority ${ }^{23}$ consider the affiliations disclaimed as constituting valid conditions for public employment and inquiry into past membership in the Communist Party as permissible without making it clear whether or not past affliation may be ground for actual disqualification. ${ }^{24}$ The reader will recall that had the oath in the Updegraff case remained in force, persons guilty of past affiliation could not have taken it in good faith; and, since their continued employment was made conditional upon taking the oath, such failure would have resulted in their discharge.

This dilemma poses the lawyer's problem which arises when he must advise his client whether he may safely take an oath with a retroactive clause. Under the Garner decision, an employce refusing to take such an oath may clearly be dismissed. Therefore, the question arises: can a former communist go ahead and take the oath and fight dismissal when it is shown that he knew of the purposes of the Party, now deemed improper, at the time of the affiliation by simply showing that there was no penalty for such membership then and dismissal now would be unconstitutional ? To squarely defeat such an argument, the court must (1) extend the position that employment by the government is only a privilege to a greater extreme $;^{25}$ and (2) conclusively decide that past affiliation is or may constitutionally be made a conclusive determinant of present loyalty. We caunot yet be certain in the belief that the present majority will accept such a position; neither is it certain that they

${ }^{22}$ To dismiss an employee for his refusal to take the oath apparently is not punishment. To dismiss him on the basis of past membership even with knowledge of a purpose, now deemed improper, innocent at the time, may be purisllment. For the affirmative argument see Douglas, J., joining Black, J., dissenting in the Garner case. 341 U. S. at 731.

${ }_{23}$ Justices Clark, Frankfurter, Jackson, Minton, Reed and Vinson.

24 The Cummings case, supra note 20 , may still have enough vitality so that when a case arises which squarely presents the issue, part of the majority may join Justices Black, Burton and Douglas in declaring a dismissal for past conduet, knowing affliation a bill of attainder. United States $\nabla$. Lovett, $328 \mathrm{U}$. S. 303 (1946).

${ }_{25}$ Washington v. Clark, supra, note 1; United Public Workers v. Mitchell, 330 U. S. 75 (1947). 
will not. Wherever the retrospective clause exists, the man or woman guilty of a past affiliation, now proseribed, may choose between two alternatives: (1) to take the oath, thereby committing perjury, and hope to invoke the rule of the Cummings case ${ }^{28}$ or, (2) resign from public employment. It should evoke in us a degree of indignation whenever a citizen of the United States is obliged to follow one of two such equally undesirable courses. But, as our staunchest "red-baiters" will argue-therein lies the supreme effcacy of the loyalty oath.

${ }^{20}$ Supra, note 20. 